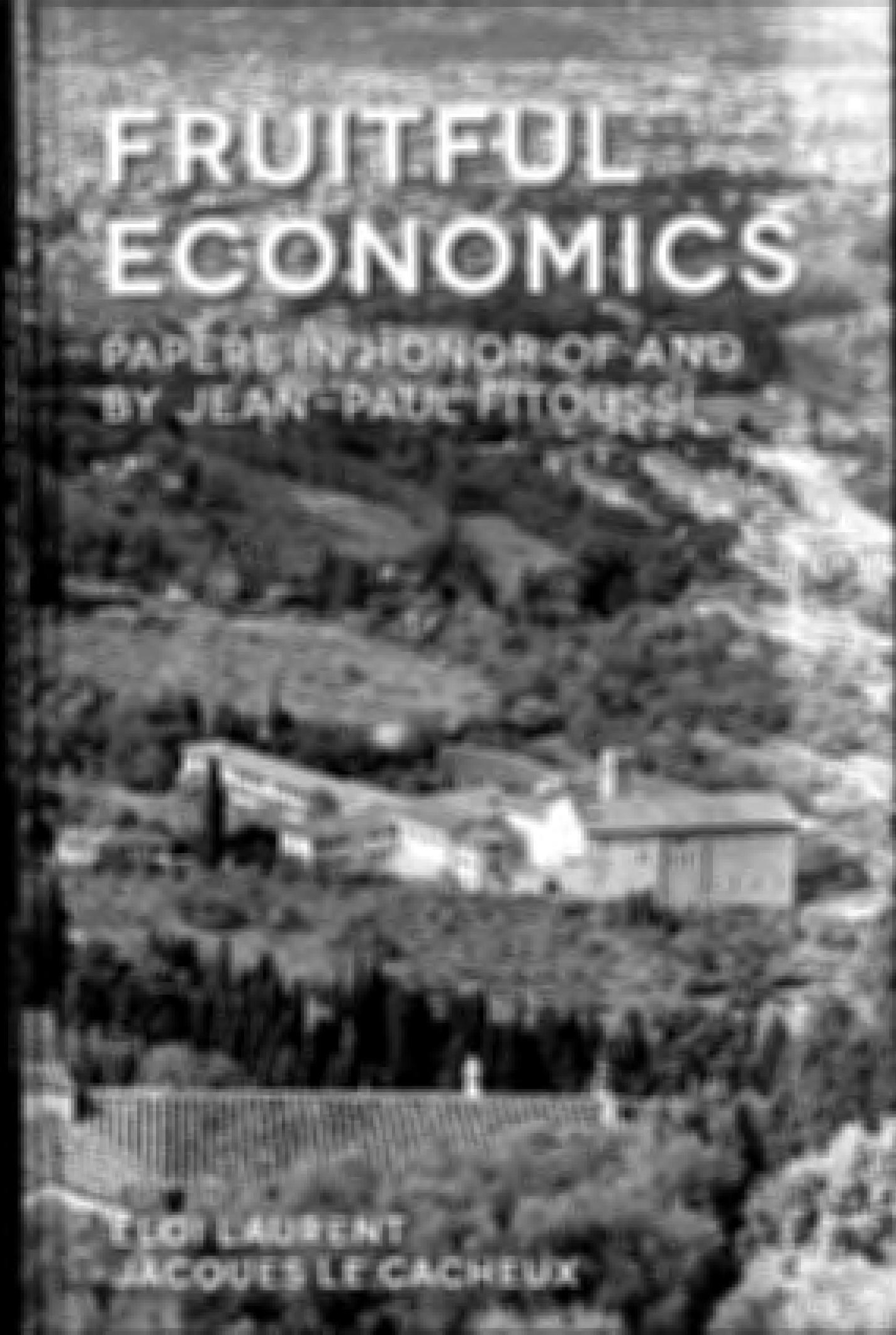


1

\section{Reconstructing Macroeconomic Theory to Manage Economic Policy}

Joseph E. Stightz

It is a great pleasure for me to participate in this event celebrating Jear. Paul Jitoussi's contribution to economics and to public life. There are so many aspects of his work and of his collaborations over a long period of years on which I feel I shotild comment: His role, for instance, in the Intemational Commission on the Measurement of Economic Performance and Social progress, has provided a critical impetus to what is now a major global movement. The commission's work was not just about measurement; in was about shaping our society, for what we measure affects what we do. ${ }^{2}$ s should tak too about his contributions over a quarter century to the lnternational scononic Association, where he served as Secretary General, and which he continues to advise. I could talk as well about his efforts to reshape the G20 agenda when France chaired that gromp, ${ }^{2}$ or the work we did together in the Commission of Experts of the president of the United Nations General Assembly on Reforms of the International Monetary and Financial System, in the altermath of the global tinancial crisis. ${ }^{3}$

But I have been asked to talk about macroeconomics, where mitoussi has been a persistent advocate of policies that maintain full employment and institutional refoms, which woud make it more likely that such policies would be adopted. But, of course, if we are to adopt policies that ensure fill employment, we must understand why the economy often w as now - operates far below its potential. It should be evident that the macroeconomic models that predommated before the crisis were inadequate. We have to reconstruct macroeconomic theory if we are to do a better job in managing economy policy - the stbject of this session, and the subject of much of Fitoussi's life's work.

The subject itself reflects a distinctive aspect of his work: a deep commitment to economic science, to the notion that economic policy has to be rooted in an understanding of economic fundamentals; and a deep commitment to policy - to the notion that our knowledge, such as it is, cannot remain within the ivory tower, and must be used to the betterment of mankind. Th belief in democracy and democratic institutions has meant that he has worked hard not only to advocate institutions, such as central banks, which are more democratically accotuntable, but to translate the abstract ideas of economic theorists into a language that is more widely understandable. If our democracy and our economy are to work, there must be more of those with the dedication that Jeanm paul Futoussi has demonstrated.

\section{Why macroeconomics needs to be reconstructed ${ }^{4}$}

No one would, or at least should, say that macroeconomics has done well in recent years. The standatd models not only didn't predict the Great Recession, they also said it couldn't happen - bubbles don't exist in well-tunctioning economies of the kind assumed in the standard model. Not surprisingly, even after the bubble broke, the models didn't predict the full consequences, and they haven't provided good guidance to policymakers in responding to the cuisis. A half decade after the bursting of the bubbte, US unemployment is still high - with almost one out of eight Americans who would like a full-tme job not being able to get one. The goverment is still financing almost all mortgages.

So, too, our standard models didn't predict etther the occurrence of or the follow-on from the euro crisis - neither ts occurrence nor its evolution, including the high levels of unemployment that persist today, and a downturn that in some countries is comparable to that of the Great Depression.

The assertions about how well the economy was performing just before the crisis by those who relied on such models are a painful testament to how badly our models performed. As Robert Wade ${ }^{6}$ has written:

In April 2006 Anne Krueger, deputy managing director of the IMFr announced the IMF's view that "the world economy has rarely been in better shape." In May 2007, Jean-Philippe Cotis, the chief economist of the OECD, presented the OECD's view that "the current economic situation is in many ways better than what we have experienced in years... Our central forecast remains quite benign... (we expect the $\mathrm{OECD}$ to show strong job creation and falling unemployment, ${ }^{\prime \prime}$

These assertions of confidence in the economy were made after the housing bubble - which was the precipitating event that brought on 
the crisis -.. had already broken. Even after the bubble broke, Bernanke predicted that the crisis would be contained. Their record in seeing that there was a bubble, let alone predicting when it would burst, was perhaps even more dismal. When shortly before the bubble broke, Greenspar was asked whether there was a bubble, he replied that there was not ... just "a little froth" on the economy.

The test of science is prediction - and one should have some skepticism of a model that can't predict the two biggest macroevents of the last 80 years. A model whose predictive ability is so weak, it can hardiy be relied upon for policy guidance. With so many of the same policy. makers in place after the chisis as before, relying on the same flawed models, it is no wonder that our recovery from the crisis has been so disappointing. ${ }^{11}$

Those who were so optimistic about the economy even as it was about to implode were guided in their assertions by the prevalent models. Not only did such models deny the existence of bubbles - in spite of more than two centuries in which capitalism had been marked by volatility, much of it brought about by credit and asset bubbles - the models asserted that even if there were a bubble, globalzation had enabled the effects of its breaking to be diversified away. They didn't even contemplate that the effects could have been amplified ira a process of contagion.

It is remarkable, given how poorly the models performed, how complacent some of the advocates of the model have been. Defenders of the model (such as Ben Bernanke) argue that the models actually worked quite well - for the purposes for which they were intended:

The standard models were designed for ...non-crisis periods, and they have proven quite useful in that context. ${ }^{\text {i2 }}$

Indeed, Bernanke argued that there was little wrong with the models themselves:

the recent financial crisis was more a falure of economic engineering and economic management than ... of economic science. ${ }^{13}$

Defenders of the model often go further, arguing that no model could deal with events that happen once in 80 years, accidents of nature that are intrinsically unpredictable. But this misses three essential points: (1) The econony wasn't teally performing well, in a fundamental sense, priot to the crisis; it was setting up the conditions - the excesses - that led to the crisis; (2) The cisis itself was not just the result of an "accident," an exogenous event that struck the economy; tather the ctisis was created, or at least enabled, by the economic policies that Bemanke and Greenspan pushed; And (3) the benefits of slightly better performance in prediction in times of "normal" economic activity are far outweighed by the fallutes in prediction in the context of deep downturns. If we are concerned with overall societal welfate, macroeconomics should be focused on these deep downturns. Between the US and Europe, the loss in output as a result of the current downtum amounts to well over five tritlion follars, an amount fat in excess of the benefits from improved fine-tuning of the economy in normal times over decades. ${ }^{\mathrm{I} 4}$

Embarrassingly, some of the defenders of the current models go even further. One, Ed Frescott, gloated that this is the "golden age of economics. ${ }^{m 5}$

\section{Back to the beginning ${ }^{16}$}

The tite of the session provides a nutshell summary of today's predicament. Prior to Keynes, there was, among classical economists, the general bellef that markets worked well, that they were stable and efficient. Indeed, so strongly were these beliefs held that in the midst of the Great Depression, a majority of American economists supported the rotion that government should do nothing. Markets would self-correct. (These economists did not, of course, explain why matters had gone so disastrously.)

Keynes provided an answer - a theoretical model, or perhaps more accurately, a set of theoretical models, with clear policy implications, the central tenets of which were: (a) markets were not self-correcting, at least in the relevant time span - unemployment could persist; (b) in deep downturns, monetary policy was ineffective; and (c) fiscal policy government spending - cotld stimulate the economy, by a multiple of the amount that was spent.

The model provided an explanation both for the disaster that was associated with US President Herbert Hoover's economic policies and for the successes of the New Deal and the wat-led recovery in the US. Keynes's ideas were incorporated in 1946 US legislation that recognized the responsibitity of the government to maintan the economy at full employment, and entrusted the Council of Economic Advisers with formulating macroeconomic policies that would ensure that this would be achieved. In the ensuing decades, there were several instances - most notably under President John I. Kennedy - where Keynesian ideas were tried and tested, and worked. 
But Keynes was never liked by those who believed in unfettered markets - who wanted to minimize the role of government - and the counterattack that began in the 1960 s had remarkable successes in the ensuing decades. Prosperity meant that the Great Depression quickly faded into ancient history, and the problem of the day was inflation, not unemployment. The economics profession changed, too, demanding greater standards of rigor. The schism between microeconomics, which focused on well-functioning markets (which always "cleared," so that there was never any unemployment), and in which the central result was Smith's invisible hand, and macroeconomics, which focused on dysfunctionat markets, which could be characterized by high levels of unemployment, was unsettling

Modem macroeconomics can be viewed as growing out of an attempt to reconcile traditional Keynesian macroeconomics with microeconom ics. ${ }^{17}$ There were two ways to achieve such a reconcilation: try to adapt macroeconomics to the mictoeconomic modet of the time, or try to glean from macroeconomics insights about what was wrong with the traditional microeconomic models and reform them accordingly. Much of the mainstream of economics took the former course - just at the time that standard microeconomics was itself under attack, from the proponents of theories of imperfect and asymmetric information, game theory, and behaviotal economics.

Mainstream macroeconomics came to be dominated by two "churches" - I use the term advisedly, because both were dominated by strong beliefs, which could be little altered by evidence and experience, though the style of argument seemed to suggest that both based their fatth on a close examination of the empirical record.

One school returned to the doctrines of the classical economists, holding that markets worked well, that policy intervention was unnecessary. Some took the (seemingly absurd) view that what was widely viewed as unemployment was actually just leisure. Their theories were designed to explain the wide fluctuations in the demand for leisure. When challenged with the observation that normally, when individuats are experiencing a period of extensive leisure, they feel happy, and yet there were ample indicators that in recessions, that was not the case, they responded: that was a matter for psychologists, not for economists.

They held two further, somewhat contradictory positions: government policy was likely to be ineffective, and, if and when it had effects, it was counterproductive.

In support of theit models, they took a major step backwart from the use of statistical inference. They constructed callbrated models, and using simulations, described the correlations between certain selected variables, comparing those correlations with observed correlations. In many cases, when one looked at the underlying behaviot, for example, of savings or labor supply, it was in fact poorly aescribed by the model. What had begun as an attempt to reconcile macro- and microbehavior seemed, in the end, to almost ignose what should have been the underlying microfoundations.

Bart of the reason for the fallure of these models was their reliance on the concept of the fully rational representative agent with rational expectations - the notion that the economy could be well described as if it consisted of a group of identical such individuals. Such models couldn't embrace information asymmetres: with a tepresentative agent, these could only arise if the individual suffered from acute schizophrenia, which would in turn be hara to reconcile with their assumptions of all-knowing tationality.

Moreover, it is hard to have a robust financial sector in representative agent models: who is lending to whom? Since all risk is bone by the same (representative) agent, financial structure can't matter. Not surprisingly, banks then play no role. With the financial sector at the center of this, and mary other crises, it is no wonder that these motels had little to say - either before or after the crisis.

The belief in rational agents with rational expectations was taken almost as an article of fath. My own research into equilibrium models with asymmetric information but rational expectations clearly demonstrates the need for behavioral economics: even if models with informam tion asymmetries but rational agents with rational expectations are able to explain many phenomera that the standard model with perfect infor. mation fails to account for, there are many important phenomena that simply cannot be explatned even within that model. ${ }^{13}$ It should be clear, too, that the behavior of so many market participants in the run-up to the 2008 crisis cannot be reconciled with any model of "rational bethavior with rational expectations," even if there were some market participants who profitably exploited others' irrationality.

The second of the two mainstream "churches" was a little - but only a little $\cdots$ better. It too relied on variants of the representative agent model, maximizing utility over an infinite lifetime, with rational expectations. Accordingly, tt too largely ignored financial markets, credit, and a host of other behavior hard to reconcile with observed macro- and microbehavion.

It can be thought of growing out of the Hicksian fixed wage/price interpretation of Keynes. While basing itself on the standard competitive 
equilibrim framework, they recognized that there could be unemploy. ment, and the challenge was how to reconcile this reality with the standard competitive equilibrium model. There was a simple answer: a single market fallure - prices and wages didn't adjust to the equilibrim level. It was the smallest deviation from the standard competitive equinbrim model that could give rise to persistent unemployment. But the fact that such a model could explain persistent unemployment doesn't in fact mean that it provides a good explanation of what has actually occurred; it doesn't mean that the model is a "good" model.

This particular chutch had implications that were as pernicious as the first. It essentially blamed the victim for tnemployment. If only workers would accept lower wages then unemployment would disappear, and the economy would be restored to its potential. The belief in this notion helps explain why central bankers, rather than sticking to their own knitting - trying to ensure financial stability - were so fond of discussing labor market igidities. $\mathrm{ut}$ was unions and government intervention in labor markets (through labot protection legislation, minimum wages, etc.) that were at the root of the problem. If only govemment allowed markets to work as markets then the macroeconomy would behave as classical economists had predicted.

But this was nonsense and was shown so by the current crisis. In the initial years of the crisis, the United States, with purportedly the most flexible labor market anong the advanced countries, performed in many ways far more poorly than the Northern European countries.

But the idea had long before been discredited: there are many economies with weak or essentially nonexistent unions and ittle or no effectively enforced government protections that are marked by high levels of unemployment. .9 With Easterly and Islam, I sought to explain the levels of volatility across countries: excessive financialization appeared more important than wage rigidities. ${ }^{20}$

Some advocates of these models recognize its limitations, arguing that it is, however, just the beginning of a research strategy that will, over time, bring in more and more of the relevant complexities of the world. Anything left out - agency problems, financial constraints, and so on will eventually be incorporated. (And especially since the crisis, DSGE models incorporating some of these features have been constructed.) To the contrary, I believe these models are not a good stating point. Such Ptolemaic exercises in economics will be no more successful than they wer in astronomy in dealing with the facts of the Copernican revolution.

It should be clear then why a reconstuction of macroeconomics is necessary.

\section{The foundations of a reconstruction}

Orice one goes beyond the standard competitive equilibrium model, one can easily explain matket failures, including markets that do not clear. (It is real rigidities, not nominal rigidities, that, for instance, should be relevant for the fallure of the labor market to clear.) Indeed, the presumption that makkets were efficient (Adam Smith's invisible hand) was reversed by the Greenwald-Stiglitz theorem, ${ }^{21}$ which showed that whenever there was asymmetric information or imperfect risk markets - that is, essentially aways - markets are not constrained pareto efficient faking into account the costs of obtaining information and creating risk markets). That has some important implications: privately profitable transactions may not be socially desirable. The banks may have incentives to engage in contracts with each other that make, for instance, the economic system more unstable (which is exactly what they did). There are impor tant (pecuniary) extermalties associated with individuals' actions that matter and which individuals do not take into account. Price changes have not just distributive consequences, but atso shift incentive compat ibility, self-selection, and collateral constraints. ${ }^{22}$

These models not only provide a better explanation of the rigidities that exist (providing an explanation for real rigidities, e.g., in wages, as a result of efficiency wage effects ${ }^{23}, 24$ ), but suggest that there are other market fallures - for instance, the fallure of contracts to be fllly indexed -... with significant macroeconomic consequences. They pick up strands of thought in Keynes (as well as others, like Fishet ${ }^{25}$ ) suggesting that wage and price flexibility may be a problem: with unindexed contracts, real debt burdens worsen as wages and prices fall. They thus suggest that the natural dynamics of the economy may be unstable - the fall in wages and prices in response to a downturn may exacerbate the downtum, not correct it.

It is strange, in fact, that macroeconomic theories focusing on wage and price igidities became so fashionable, when in the Great Depression, wages and prices fell so deeply and rapidly. Would things have been better if they fell even faster? ${ }^{26}$

This ullustrates another incoherence in the standard model the more rapid fall would have led to higher teal interest rates, given that the nominal interest rate can't fall below zero. The standard model foctises on the role of real interest rates. If so, more wage and price flexibility would have made matters worse. Of course, if real interest rates played the central role that the standard models assert, even with a zero lower bound, there would be an easy way to lower the real interest rate, 
through tax policy. A large but declining investment tax credit would confront firms with intertemporal choices that are similar to those associated with high real interest rates.

But I don't believe, especially today, that the zero lower bound on nominal interest rates is the central problem, the critical impediment to the restoration of the economy to full employment. Real interest rates in the United States are already $-2 \%$. Does anyone really believe that lowering then to $-4 \%$ would solve the economy's problem? To be sure, a sufficiently large negative real interest rate might make a difference, but such a change would entall such an increase in uncertainty that we cannot be sure even of the direction of the effect. (I will return to this issue later.)

Again, the representative agent model (and its descendants) imposed a straightjacket that made it difficult to think clearly about what was going on. The problem was not just that the I-bill rate couldn't be negative, but the unavallability of credit to firms and the adverse terms at which such credit was avallabte. The spread between the lending rate and the borrowing rate was endogenous. There could be credit rationing indeed, the inability of banks to bortow was the liquidity crisis that brought on the downturn. To me, the strangest aspect of modern macroecononics was that central banks were using a model in which banks and financial markets played no rote.

\section{The central questions of macroeconomics}

Thus, for me, the reconstruction of macroeconomics based on alternative models to those of the two prevailing "churches" of mainstream economics is likely to provide better answers to the three central questions underlying deep downturns, and thus to provide better guidance for economic policy:

a. What is the souce of the disturbances? The standard models assumed that they were exogenous technology shocks - by implication, the Gredt Depression was marked by an episode of acute amnesia, where in large parts of the world, people got less productive! The reality was that this and most other major downturns are man-made events. ${ }^{27}$ The system creates them. And that means it may be possible for us to at least reduce their frequency and depth.

b. Why do semingly small shocks (after all, even the sub-prime mortgage market was only a small fraction of global weatth) have such large effects? Standard theories describe the economy's buffers - how, for instance, price and inventory adustments help stabilize the economy.
Instead, it seems that the svstem often amplifies shocks, ${ }^{28}$ And shocks spread, like a contagious disease. Indeed, a central concern of policy makers after a shock is preventing contagion. But the standara models say that interdependence - global diversification - contributes to stability. Their implicit recommendation for a group of indivicuals found to have smallpox wotld be global diversiffation - send a few with the disease to each locality. But we all know that this would have spread the risk and amplifted the problem.

c. Why do deep downtums last so long? Why does there seem to be such persistence? After all, we have the same human, physical, and natural resources today as we had before the crisis. If markets worked well, we would quickly be restored to full employment. Debt can't be the problem; after all, debt is just money that we owe to ourselves. It is a matter of distribution, and in the standark models, distribution doesn't matter. And even if debt did matter because cistribution matters), standard theory says that there is still a new full employment equilbrium. The standard theory provides no explanation for why we don't quickly get there, other than wage and price rigicities. We should note that the losses after the breaking of the bubble are far latger than those associated with the massive misallocation of capital ptior to the crisis. Moreover, the state variables (capital stock, labor supply, human capital) change slowly. If (as in the standard model) there was a continuous mapping from state variables to the value of market equilibrium variables, then presumably the requisite change in wages and prices would be small, so that even with imperfectly flexible wages and prices, the aggregate loss from the rigidities would be small. This wolld not, of course, be the case if there were multiple equilibria, so that (with the same state variables) the economy's equilibtium could change dramatically. 29 is is, in fact, easy to construct models with such multiple equilibria, once one leaves the world of representative agents. There can ever be multiple rational expectation equilibria. ${ }^{30}$

Recently, I have been working on models in which there can be large changes in perceived wealth. ${ }^{31}$ When individuals have different expectations (which can eastly occur in the presence of differences in information even with rational expectations), then there is scope for them to engage in bets. Each of the two sides believes (in expectation) that they will win, and the sum of the believed wealth exceds the "true" wealth. 1 refer to this perceived wealth as "psendo-wealth." Of course, next period, when the bets are settled, one side of the bet will wint the 
other lose, and pseudo-wealth will get destroyed. But if differences in beliefs persist, then new pseudo-wealth will be created.

But if, for some reason, there are changes in the economy stoch that the ability and/or willingness to engage in such pseudo-wealth creation changes, then the total perceived wealth of the economy can change quickly. There will then be large changes (at current wages and prices) in levels of consumption and investment and other aspects of economic activity (lending). Such changes can occur even if prices themselves are actuarially accurate; but even more so if (as in Scheinkman et al ${ }^{32}$ ) prices differ from actuatial value, and the disparity between the two can change quickly. An event such as the bursting of a real estate bubble can changeboth the ability and willingness to engage in bets (and thus the level of pseudo-wealth in the economy), and the magnitude of the dispanty of beliefs (before the crisis, some believed that there was a bubble, others that there was not; after the crisis, it was clear that there had been a bubble).

Indeed, a crisis can give rise to the rapid creation of negative pseudo-wealth, as creditors become more pessimistic about the ability of borrowers to repay their loans, while borrowers believe that they will repay (and act accordingly).

The theory of pseudo-wealth can explain how, even when there are small changes in the standard state variables (physical, human, and natural capitai), there can be large changes in macroeconomic behavior (in, for instance, aggregate consumption), for there can be large changes in perceived wealth, and the effects of these changes may not easily be offset by changes in relative prices - including interest tates.

I do not have time to flesh out furthes how this teconstruction of macroeconomics (as it has proceeded so far and how it may proceed in coming years) provides answers to these three questions. I want to move on, however, to how these theories, even in their imperfect state of development, provide policy frameworks that are far more likely to produce better macroeconomic performance - illustrating the links between theory and policy that have been the hallmark of Fitoussi's work.

\section{Importance of inequality}

First, though, I want to highlight one aspect of Fitoussi's work that is essential to understanding why the policy recommendations that he has urged - and which I believe are correct - dffer so markedly from those of the standard model. It is that distribution matters. If one is concerned about social justice, then this is obvious. But distribution matters even if one is just concerned about economic performance. ${ }^{33}$
It matters, in particular, if the marginal propensity to consume differs significantly for at the top and those at the bottom. While there is overwhelming evidence that that is the case ${ }^{34}$ - reinforced by recent work focusing on consumption behavior in this recession ${ }^{35}$ where are still those who believe to the contrary, citing Muton hriedman's classic work. But Friedman, a devotee of free market economics, not surprisingly ignored the importance of credit constraints; which explain why those at the bottom might have a higher marginal propensity to consume than those at the top. ${ }^{36}$

Greenwald and Stiglitz (1993, op cit) have also shown that the distribution of net worth among fims also matters. An increase in the relative price of oil benefits oil producers at the expense of the oll uses; but the latter are likely to contract output, employment, and investment as a result far more than the former increase output, employment, and investment, so that such a change will have a contractionary macroeconomic effect. But the same would be true for a dectease in the relative price of oil.

It is worth noting that to those on the right, this attention on distribution is an anathema. As Robert Lucas forcefully put it,

of the tendencies that are hammful to sound economics, the most seductive and ... poisonous is to focus on questions of distribution. ${ }^{37}$

I might suggest that, to the contraty, of the tendencies that have marked modern macroeconomics, the most seductive and poisonous is the failure to pay due attention to inequality.

\section{Policy frameworks}

I begin my discussion of policy frameworks with two ideas that have played a central role in recent policy discourse: can austerity work, and can government spending work? I then discuss the limitations of monetary policy.

Filouss has been particulatly focused on how the answers to these questions are affected by a country being a member of a currency union, and 1 shall accordingly discuss the answers to these questions both in the context of the US and the countries in the Eurozone.

\section{A. Austerity and contractionary expansion ${ }^{38}$}

The notion that the government could restore the economy to health by cutting back on spending - contractionary expansions - is one of 
the strangest to have amerged in recent policy debates. Yet, austerity is in fashion in many quarters, buttressed by an occasional study (most notabiy the work of Alesina and Ardagna), ${ }^{39}$ It is remarkable that the idea ever gained fashion, and even more so after the studies that underpinned it were thoroughly discredited (even by the IMF ${ }^{40}$ ).

Hoover's austerity is widely given credit for helping turn the stock market crash of 1929 into the Great Depression; the policies that the IMF-US treasury foisted on Dast Asia and Latin America similarly converted downturns there into recessions, recessions into depressions. By now, it should be clear that austerity has not worked in Europe - with unemployment reaching record levels. This is true even though there are some who have seen in the end of the recession proof that austerity works. But the end of a tecession is not the same as a robust recovery; and even with the "ofticial" end of the recession, per capita GDP remains below what it was before the crisis, and unemployment tates, especially of youth, remain highly elevated. Several of the Luropean countries can best be described as in a depression. Moreover, the real test of the success of an economic policy is not whether the economy eventually retums to hul emplovmerit: every economic downttirn eventually comes to an end. It is the depth and duration of the downturn and the magnitude of the long-term damage. Atsterity, in these terms, has been a disaster: the cumulative gap between actual and potential output is already in the trillions. Today, the Eurozone economies are some 15 to $20 \%$ below where they would have been had there been no crisis, and the gap is not closing. Countries that engaged in less contractionary policies did less badly. I believe austerity has been a key factor in contributing to Europe's poor performance in the years since the crisis.

There have been some discussions of instances in which government cutbacks have been associated with economic expansion. Sorne have suggested that these benefits arise from supply side responses (e.g., as a result of the lower tax tates, now or in the future, there is a negative balanced-budget multiplier). But in situations such as the current one, where aggresate demand is limiting output, supply side responses can even increase unemployment and have an adverse effect on output: the downward pressure on wages shifts the distribution of income toward profits, lowering aggregate demand. This suggests that the few instances of govermment cutbacks bringing on expansion must be special and peculiar. And indeed that is the case: they happened in small countries that had the good fortume to have exports expand more than enough to fill the gap in aggregate demand caused by reduced government experditures.
They are typically instances where (a) the country's trading partners were growing, so the export market was expanding; and (b) the country had a flexible exchange rate, so it could quickly become more competitive by lowering interest rates or undertaking other policies that affect the exchange rate.

For Europe and America now, the notion that exports could fill the gap created by teduced government spending is a chimera, especially in view of the current global slowdown. And this is especially so for the weak countries in Europe. With their flxed exchange rate with their major trading partners in Europe, austerity is designed to improve competiveness by forcing down wages and prices, in a process called internal devaluation. But internal devaluation has never worked to restore an economy to health, partly because the decreased wages increases the burden of debts denominated in euros. The decreased demand for nontradeables typically more than oftsets any gains from increased exports.

But looking across Europe, the growth in exports has been at best disappointing; the improvements in the current accourt position are mainly a result of the decreased imports as a restlt of lower incomes. (Pat of the reason for this is that the $\mathrm{BC}$, focusing on inflation, allowed interest rates to remain high relative to those in the US, increasing the value of the euro.)

Perhaps the strongest criticism of this approach to economic recovery is (to the exterit it is successful) it is a policy that is aimed more at shifting demand away from others than at increasing global aggregate demand. ${ }^{41}$ Indeed, by lowering incomes in the afficted countries and increasing the burdens of their debts, it reduces global aggregate demand.

But for those in the Eurozone, with an exchange rate that cannot adjust, with a single market, where capital (in principal) can flow freely, and with a single currency but without the institutions necessary to make a single currency work, the abandomment of austerity - without further reforms in the structure of the Eurozone - poses its own problems: Weaknesses in Spain and Greece, for instance, are caused not just: by the lack of government spending, but by lack of lending - an almost inevitable consequence of the failure to have a banking union. With a weak private sector, the burden on government is all the greater. And if somehow, the economy is restored to full employment, large current account deficts are likely to show up in mariy of the countries.

If a single currency is to work, then, not only must the policies of austerity be reversed, but other reforms in the structure of the Eurozone, its policies, and its institutions will have to be undertaken. At a minimum, there will have to be some form of mutualization of debt, a tobust 
banking union, with common supervision, resolution, and most important, deposit insurance, and a convergence strategy.

Here is where Eutope failed most - in its diagnosis of what was required for convergence, for the countries to be sufficiently similar that they colld share a common currency. The Maastricht convention was based on neoliberal notions that, lf only the government managed the macroeconomy well. the private sector would ensure that all else would go well. Thus, the ECB was given the mandate of erisuring price stability, and the growth and stability pact reguired that countries joining the euro would have low deficits (under $3 \%$ of GDP) and low debt (under $60 \%$ of GDP). But as country after country went into crisis, it became clear that these conditions were neither necessary nor sufficient for convergence. Spain and Ireland both had surpluses and low debt-to-GDP ratios before the crisis, and yet, after Greece, they were the first to join the long list of countries facing difficulties. It was clear that it was private sector excesses that were at fatlt, not government excesses, and yet the Eurozone framework had no way either to detect or to respond to such excesses. Tougher agreements to make sure that fiscal imbalances do not appear in the future would not have prevented the last crisis and will not prevent the next one. But the austerity meas. ures that are now being imposed will make a full recovery from this crisis more difficult.

Long-mu convergence will require parallel increases in costs of production in the different countries, which can be achieved only through convergence of productivity and, given well-recognized downward rigidities in wages, faster wage increases in countries with higher increases in productivity. Convergence of productivity increases wil require the laggard countries to embark on industrial policies - more than just creating a "conducive environment," again as assumed by the neoliberal models. But industrial policies were effectively discouraged under the wu framewok, Convergence and growth could also be facil tated by more infrastructure irvestment, financed by the $\mathrm{EU}$ as a whole; but while there were generous funds for new entrants to the EU, funds for the lagging countries have not been sustaned.

Instead of creating a ramework that would facilitate convergence, they created one that exhibits fynamic instability: with each country responsible for its own banking system, and with confidence in a country's banking system inevitably depending on the country's ablity and willingness to bail out troubled banks, money flees weak countries and its banks, making them even weaker. Private contraction amplifies the effects of public austerity. So too, the obligation of citizens to pay for their parents misdeeds - but only if they remain in the country -minduces skilled labor to leave, increasing the burten on those remaining,

While the crisis made the problems of the euro-structure clear, they were present long before. Indeed, the euro belped create the crisis: for the markets seemed to have vastly overestmated the extent to which the single market/single curtency had reduced risk (another example of market irrationalty), leading to excessive lending to the afficted countries. And the structure of the Eurozone, based on neoliberal doctrines of efficient and stable markets, provided no way to curb the excesses thus generated.

\section{B. The multiplier ${ }^{42}$}

Those on the inght not only believe that government action is not needed, but that it is likely to be ineffective.

There has been considerable discussion of the magnitude of the multim plier associated with govermment spending, with citics of expansionary govemment spending suggesting that it is low, zero, or even negative. They look at the experience of different comtries over long time beriods. Such analyzes shoutd be an important warning of the foolishness of mindiess regressions. Of course, when the economy is at or near full employment, the multipler (correctly measured) will be low. fven then, measurement problems (GDP is not a good measure of economic output, providing only a biased estimate of economic perfomance when the shate of govemment expenditure incteases ${ }^{43}$ ) and econometric problems bedevil such analyses. But the question is, what will the multiplier be when there is a high level of unemployment and large underutilization of capacity? Since we have not had the levels of unemployment and capacity utilization that we ate now experiencing since the Great Depression of the 1930 s - and the structure of the economy was markedly different during the Great Depression than now - there is no way we can, with confidence, extrapolate the expetiences of previous post - Depression downtums to the current stuation. ${ }^{44}$

Economic theory, though, provides a compeling framework for aralysis. The problem is lack of aggregate demand. Govemment spending increases aggregate demant. We can identify leakages (from savings and imports) and, on the basis of that, calculate the multiplier. Traditional analyses, based on downtums of short duration, focused on one-period multipliers: two years from now, the thinking went, the economy would presumably be back to full employment, and the multiplier would be zero. but this downturn is long-term, so in calculating the multiplier, we should calculate the impacts not just for this period, but for subsequent periods as well. 
For the United States, this kind of analysis yields a muti-period multpher (with reasonable values of savings and import coeffictents) in the range of 1.5 to 2

The next question is: are there reasons to believe that there are reactions from market participants that will amplify or reduce these effects, that is, are there "crowding in" or "crowding out" effects? Again, in normal periods, the Central Bank, worried about an overheated economy, raises interest rates and tighteris credit, discouraging investment. The result is that government spending crowds out private investment. But now, the led is committed to keeping interest rates low and doing what it can to increase the avallability of credit. This explains again both why estimates of the multiplier based on nomal periods are irrelevant, and why, in this case, the multiplier will not be reduced by crowding out of investment.

Thete may, in fact, be crowding in of investment - if govenment spending, for example, goes to public investment, and public investment is complementary to private investment. Alexander Field, ${ }^{4.5}$ for instance, makes a persiasive case for the theory that infrastructure investment during the Depression enhanced private sector productivity, and that this helped lay the foundations for strong growth after World War II. More recently, government investments in the Internet and the life sciences have clearly spawned entre inclustres.

The Barro-Ricardo hypothesis suggests that the increased indebtedness of government will lead to more savings (to offset future tax liabilities), and thus that government debt financed spending crowds out consump tion. There is little evidence of such an effect in recent years; in fact, the Bush tax cuts gave rise to soaring deficits, which were followed by savings falling to near zero. ${ }^{46}$ To believe in the Barro-Ricardo model, one would have to hypothesize that in the absence of the tax cut, savings would have been markedly negative.

The criticisms of the hypothesis are well known: it ignores capital constraints and distributive effects. Indeed, there may even be "crowding $\mathrm{in}^{\prime \prime}$ of consumption. pirst, if govemment spending is for high-retum investment, in a period such as the current one where government can borrow at a negative real interest rate, the government's balance sheet will be improved; thus (in the world of rationality, in which taxpayers see through the public veil), savings would be reduced. ${ }^{4}$ There would be crowding in of consumption, not crowding out.

Moreover, if, as we have already noted is the case now, the downturn is Ikelly to exteria for several periods, some of today's savings will be for future consumption; with rational expectations, individuals would then know that incomes in future periods will be higher than they otherwist would have been, meaning that their lifetime budget constraint has moved ont. This agam leads to increased consumption today.

Of course, a good multiplier analysis takes into account the fact that different kinds of expenditures have different multipliers. What matters is not what the average multipler has been in the past, but the effect of a well-designed expansionary policy today. We have suggested that spending on investments in the US today on education or research has a far higher multiplier, say, than on contractors in lrap.

For some highly indebted countries, the adcitional borrowing to finance expansionaty investmentoriented tiscal policy would come at a high price; they would have to pay increasingly higher interest rates, which might constrain what they could spend overall on outputexpanding projects ${ }^{50}$ In principle, the market should redize this, in which case the greater indebtedness could lead to a lowering of interest rates. But there is no shortage of evidence of market irrationality; and whether justified or not, if increased indebtedness leads to higher interest rates, governments may have to employ another strategy, making use of the balanced-budget multiplier.

Traditional analyses suggested that the balanced budget multiplier is unity. But well-designed increases in taxes and expenditures can have a balanced-budget multipler that is much larger, plausibly twice the traditional number, for example, recognizing that the marginal propensity to consume at the top is low relative to that elsewhere, and tax hikes at the very top recuce consumption by far less than the increased expenditures expand it. Taking advantage of cowding in of consumption and invest ment can further enhance the balanced-budget multipler.

Indeed, there are some taxes that might even stimulate demand. An increase in the estate tax would encourage the elderly to consume more today; the imposition of a cabon tax would encourage investment in buldings and equipment that reduced carbon emissions. So too might an increase in a tax on dividerids.

In short, there is every reason to believe that well-designed government policies could be very effective in stimulating the economy. Keynes was right about there being a multiplier - and advances since ther have shown how that multiplier car actually be kncreased.

\section{Debt and deleveraging}

There are many in Europe and Arnerica who believe that our current troubles arise from excess debt, at both the household and national level. Those focusing on debt at the national level have warned that debt financed 
spending will be counterproductive in the longrun. Much of this view has been based on the now discredited work of Reirhardt and Rogoff, who contended that once debt exceeded 90\%, the adverse effect on growth increased significantly. Interestingly, they never tested the hypothesis they never checked the statistical significance of any observed differences in growth of countries with tebt-to-GD) ratios below and above $90 \%,{ }^{52}$ A large literature has now called attention to other fallings - the lack of attention to causality (it was the recession that caused slow growth, not the other way around); to the difference in circumstances. Does it make a difference whether the debt is borrowed in one's own currency or in another currency? Whether one is a reserve currency country? Was the debt generated by war or by gross incompetence? America left Worto War II with a debt of $130 \%$ of GDP, and yet in the ensuing decades the country experienced its fastest rate of growth (and the growth was shared growth). So too, Martin Wolf has commented that if debt held back growth, England would mever have experienced the industrial revolution, for it emerged from its wars with france with massive debts. "The wide range of experiences shows at the minimum that debt is not destiny.

It is noteworthy that the debt pessimists have never come up with a coherent theory for why debt itself should lead to lower growth-except If countries listened to the debt pessimists and adopt austerity measures in response. Older literature for a closed economy emphasized that we simply owe it to ourselves - and in the standard representative agent model that would mean that there would be no effect. In the currently unfashionable life cycle models, debt can displace capital and lead to lower levels of per capita income, but it does not lead to a lower rate of growth (although in the transition period growth would be smaller). And in an oper economy increased indebtedriess to foreigners would lead to lower standards of living for the citizens (they are poorer), but not to lower rate of growth.

Private indebtedness can, however, have significamt effects - although in the neoliberal framework, whatever the private market decides is by definition "right." That ignores the pervasive market fallures that we noted earlier, associated with imperfect and asymmetric information and imperfect risk markets.

Many have pinned their hopes for a quick recovery on deleveraging. There was excess private (mainly household) debt prior to the crisis especially so once the housing bubble had broken. This indebtedness puts a damper on household spending. However, households are working down this debt. Once they do so, consumption will recover, or so it is belleved.
High leves of indebtedness do have an adverse effect on consump. tion, both becatse of the real wealth effect and because of the effect it has in imposing borrowing constraints (which my own work on imperfect capital markets, arising out of asymmetric information, has emphasized). Still, it would be foolish to think that even after deleveraging, consumption will return to anything like it was before the crisis.

The use of representative agent modes has obscured what was going on in the US betore the crisis: the bottom $80 \%$ were consuming approximately $110 \%$ of their income. Even after they deleverage, even after the firancial sector is fully restored, we shouldn't expect them to consume, on average, more than $100 \%$ of their income. With the top $20 \%$ garnering for themselves some $40 \%$ of national income, and with their savings rate being roughly $15 \%$, one should expect a national savings rate of some $6 \%$ - somewhat higher than we see today but somewhat lower than the prevaiting rate in the US in earler decades. The continuting rise in inequality provides an additional argument for why we should not expect a retum of the savings rate to pre-crisis levels.

The puzzle is why hasn't the US savings rate increased even more (from slightly more than zero to around $4.5 \%$ today). The answer may have to do with slow adjustments in consumption patterns, which are aspects perhaps not adequately incorporated into the traditional models.

If, of course, we do get recovery of the economy thtough consumption, we should be wortied: it would mean a retum to unsustainable patterns of the kind that marked the pre-crisis days.

Interestingly, the representative agent model without financial

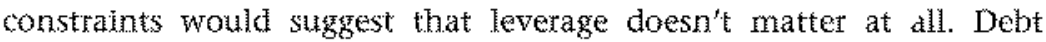
simply reflects an ownership claim on a stream of returns - a transfer of money from debtors to creditors; but such transfers have no effects in this model. 55

\section{The liquidity trap and the zero lower bound}

Before the crisis, many economists argued that monetary policy was, and should be, the man vehicle for regulating mactoeconomic activity, which the government carried out by manipulating interest rates. It was the most effactive and least distortionary instrument of govemment policies.

I have never found convincing evidence for many aspects of these doctrines, and I have always found the theoretical arguments unconvincing. Indeed, the relationship between real in terest rates and investment (especially outside of real estate) is hard to establish. In most models, if nominal and real interest rates are both put in the right-hand 
side of a regression, nominal interest rates appear to have more importance. Moreover, the notion that monetary policy is non-distortionary or at least less distortionary than fiscal policy - is a fiction that arises from the simplistic aggregative models commonly employed. Reliance on monetary policy forces adjustments to macroeconomic disturbances to be bome by interest and credit sensitive sectors. There is no general theory suggesting that making these sectors bear the cost (aimost surely shrinking these sectors relative to what they otherwise would be) is optimal in any serise.

In this crists, the Fed (along with other central banks) has lowered interest tates to near zero - real interest rates have become negative without producing much of a stimulative effect - indeed, far less than was desited or hoped. I was not surprised, knowing that in the flawed modeling of investment in the standard model credit avallability and its determinants, risk, and risk avession are given short shrift. And as we noted above, even if the l-bill rate is low, what matters is the lending rate, and the spread between the two is an endogenots variable. The lending rate may not fall in tandem with the decrease in the T-bill rate.

As Keynes' view of the inefficacy of monetary policy has seemed to tritumph, those who beleve in the standard model have suggested that its fundamental problem is the "zero lower bound" on interest rates, a variant of the Keynesian liquidity trap. But the situation daring the Great Depression was completely different from today's. Then, prices were falling at $10 \%$ a vear, so the real interest rate - as interest rates approached zero - was $10 \%, 56$ Today, the real interest rate is $-2 \%$. There is no reason to belleve that if (expectations of the inflation rate were to rise to $4 \%$ or even $6 \%$, and the real interest rate fell to $-4 \%$ or $-6 \%$, there would be a surge in investment. After all, there is excess capacity in many sectors, estecially in real estate. Getting funds at a lower rate is no reason to boost one's excess capacity. (To be sure, there is a fast enough rate of inflation to make the real interest rate negative enough to perhaps stimulate investment. But the uncertamty brought about by this change in economic policy would itself have adverse effects on investment. ${ }^{37}$ )

Again, the use of overly simplistic models has obscured some potenm tially important adverse effects of lower interest rates, including lower long-term interest rates achieved through quantitative easing. This would have the potential to partially or totally of fset the alleged benefits assumed to arise, particularly if the interest elasticity of investment is small. There are, for instance, complex distributive effects. Traditionally, over the long-run, creditors have been considered better off than debtors; that being the case, the redistributive effects seen in this scenario would be expected to enhance aggregate demand. However, if debtors have long-term fixed-interest contracts, and if there are groups tike the elderly who are dependent on the income from government T-bils and bonds, the effects may well turn out to be negative. This is especially so because the marginal propensity of the elderly to consume may be higher than that of mortgagees and/or if $\mathrm{Q}$ e results in a much greater decline in w-bill rates than in mortgage rates. ${ }^{58}$ If quantitative easing leads to commodity booms (a question that remains in contention), then there is a distributive effect from households to commodity producers, which almost surely has a downward impact on aggregate demand.

In a world of full tationality, as assumed in the traditional models, there is a further negative effect: the long-term bonds that the Fed is buying now will be sold back at a captal loss. The government is (in effect) buying long-term bonds at a peak price. Therefore, under the Barro-Ricardo hypothesis, households should rationaly include the expected capital loss in their butiget constraints and, thus, reduce consumption. (This is the case whether or not accounting rules require the government to recognize the loss, or whether or not the Fed goes through machinations to avoid selling them at a loss by holding them to maturity. ${ }^{59}$

The traditional mechanism by which lower (long-term) interest rates might benefit the economy is an increased flow of credt at better terms but that does not seem to be playing a major role today, pethaps for five reasons: (a) The firms that are most constrained by borrowing, small and medum-sized enterprises ( $\mathrm{SM}$ ), remain constrained, because the supply of funds is constrained - while the big banks were given huge amounts of money, and repaired their balance sheet through monopoly protits and speculative activities, the smaller regional and communtty banks upon whom the SMEs depend remain weak; (b) Large multinationals are awash witl trillions in cash, small changes in interest rates are not likely to induce them to invest when they were reluctant to do so before, and when they do invest, it is likely not in the US; (c) The consoldation of banks as part of the flawed attempt to preserve the banking system has led to non-competitive markets, for example, in mortgages, so that rather than just passing on lower interest rates to customers (as would happen in a competitive makket), lenders have enjoyed larger spreads; (d) In a world of globalization, money goes to where the returns are highest - and right now, that seems elsewhere than the US and Europe money is going where it's not needed and not going where it is needed; And (e) in a world of globalization, what one central bank does can (and 
often will) be undone by other central banks: one adds liquidity to the global financial system, while others take it out. ${ }^{60}$

The fed has stressed the benefits from high stock market prices. This effect, of course, is only relevant for those who own stocks. But even then, the size of the effect is questionable. The Fed has announced that its interventions are temporary. If so, why should the effects be long lasting - why should they affect long-run budget constraints? (To be sure, some may gain from selling bonds when they are high, but others will lose from selling bonds at a loss. But in a representative agent model, these should largely cancel out.) The eftects can be longer lasting, if somehow, the higher stock price shifts expectations in a way that moves the economy into another equilbrium - but again we have moved outside the standard representative agent model.

Finally, in the standard putty-clay model, firms, able to get access to long-term capital at a very low interest rate, will invest in highly capital-intensive techmologies, because wages have not fallen as much as the cost of capital. But this means that, at any given level of demand for output, employment will actualy be reduced. Thus, loose monetary policy today may be setting up the conditions for a jobless recovery in the future. Even today, the outunes of such a situation are already visible. The knowledge that weaker demand for labor lies ahead affects consumption demand cirectly and indirectly, as it puts further downward pressure on wages, worsening the distribution of income.

The importance of this is not that we should have tight monetary policy. It is that we cannot rely on monetary policy for our recovery, and that other government policies have to be put in place to oftset the potential and real advesse effects that we have described.

To return to Europe: While American monetary and regulatory policy before the crisis was flawed, both in theory and in its execution, at least the mandate of the Fed went beyond just limiting inflation - in the mistaken notion, referred to earler, that controlling intlation was necessary and almost sufficient for strong growth, Today, the Fed's mandate includes employment, output, and financial stability, and some Fed governors have advocated "employment targeting," at least until the economy returns to a more normal level of unemployment.

It was, as Fitoussi has repeatedly reminded us, a mistake to have the $E \mathrm{CB}$ focus exclusively on inflation, and th was even more of a mistake to put such a mandate in a treaty, making a change in the mandate - a change which should have been effected by changed perceptions of macroeconomics -50 difficult. But it is even more problematic in a world of global financial matkets, where the fed, focusing on unemployment, has kept interest rates neat zero, while the $\mathrm{FCB}$ has not responted in kind. The result is a stronger exchange tate and a weaker European economy. Lack of global monetary coordination has a price, but in this case, it is Europe that is bearing the brunt of the costs.

Almost surely, even with its mandate, the ECB could have taken a more aggressive stance. And this is where institutions and their design matter, something that fitoussi has repeatedly emphasized. 51 The notion of an independent central bank was sold partially on the idea that managing monetary policy was a technocratic matter, to be left to skilled technicians. Seemingly, there is a Pareto efticient monetary policy. But such a view is wrong and dangerousty so. It is wrong on several accounts.

Institutions do not exist in a vacuum: an independent central bank is effectively captured by financial markets, and it is their interests and perspectives that the bank reflects. That the technoctats are not realy in possession of the expertise that they would like the rest of us to assume they have is reflected in the fads and fashions that prevall, each believed with fervor, until they are thoroughly discredited. Monetarism, motivated in part by Fiedman's belief that the less discretion given to the government the better, captured the imagination of Central Bankers in the 1980 - just at the time that evidence was mounting that the assump tion that the velocity of circulation was constant was wrong; and just as economic theory explained why it was credit, not money, that was needed for transactions. It should also be evident that the doctrines that prevalled in the years before the crisis, most notably inflation targeting, did not serve our economies well.

All economic policies have distributive eflects. There are risks assoclated with all economic policies, and different individuals bear these risks differently. So the notion that there is a Pareto dominant monetary policy is a chimera.

\section{Concluding comments}

This is perhaps a good point to close: As keynes rightly pointed out, policy is shaped by theories. In Keynes's day, it may have been theories promulgated decades earlier. In today's word, it seems that lags have been reduced, with policy subjected to the ebb and flow of the fads and fashions in the economic profession. The fads and fashions that dominated in the decades preceding the current crisis have not served us well -. the models/theories that guded policy were not just innocent bystanders in the crists that unfolded beginning in 2008 . They were critical in the creation of the crisis and in the inadequate responses to it. Moreover, as 
1 argue in my book The Price of Inequality, these theories were also not innocent bystanders to the growth in inequality that has marked recent decades; the policies based on these theories were an important factor in the marked increase in inequality over the past 30 years

For decades, fitoussi has been one of the few voices holding out against these intellectual trends. Ite irisisted that models be based on common sense, that the common sense be informed by historical expertence as well as empirical evidence. In the end, the theories he has pushed and the policies that are derived from them provide a far beter understanding of our macroeconomy than the currently fashionable ones. But they also provide the basis of policies that ate more consistent with underlying values of social justice, and democratic accountability and process. ${ }^{62}$

\section{Notes}

1. This essay owes an enomous intellectual debt to Jean-Pat Fitoussi. I should also acknowledge helpful discussions with Rob Johnson and my long-term collaborator, Mruce Greenwald. Financial support from INET is gratefully acknowledged. Research and editorial assistance were provided by lamon Kircher-Aller and Sandesh Dhungana. University Professor, Columbia University.J. Fitoussi, A. Sen, and J. E. Stiglitz: Mismeasuring Our Lives: Why $G D P$ Doesn't Add Up, New York: The New Press, 2010

2. The G20 and Recovery and Beyond: An Agenda for Global Governante for the Twenty-first Century, JP. Fitouss and I. E. Stiglitz (eds), ebook with contributions from The Paris Group, 2011.

3. Avallable as The Stiglitz Report: Reforming the International Monetay and Financial Systems in the Wizk of the Global crists, New York: The New Press, 2010. Some of the topics that I touch upon below are related to this and the previous two reports.

4. This paper draws heavily upon two ptevious lectures have given on telated subiects, the Adam Smith lecture to the extropean Economic Association, "Rethinking Macroeconomics: What Fatled and How to Repair It, "Joumal of the Buropeat Economic Association, 9(4): pp. 591-645; and a lecture to the Turkish Economic Association annual meeting, November 2013, "Stable Growth in an Era of Crises: Leaning from Econonic Theory and History," forthcoming in Economi-fek, the joumal of the Turkish Econontic Association, as well as my book Freefall: America, Free Markets, and the Sinking of the World Economy, New York: WW Norton, 2010.

5. Figure is current as of the time this paper went to press in May 2014. But for most of the four years since the Great Recession ended, this figute was 1 in 6 , or worse.

6. Robert H. Wade: "What economists should have Ieaned from the Westem Financial Crash and Long Slump: inequality, financial globalization, and macoeconomics," lecture presented at seminar on Globalization, Development and hequality, Bangalore, January 8,2013 , in conjunction with 6 th Anmual Advanced Graduate Workshop on Poverty, Globalization and Development, Azim Premil University, Bangalore.
7. Quoted in Stewart Lansley: The Cost of Ineduality, London: Gibson Square, 2012, p. 224.

8. I. P. Cotis: "Editorial: achieving futher rebalancing", OECD Economic Outfook, 1: pp. 7 10 (at p. 7), 2007.

9. See e.g. "Chatman Ben S. Bernanke. The Economic Outlook. Before the Joint Economic Committee, U.S. Congress," Match 27, 2007, avalabie at http:/www.federalreserve,gov/newsevents/testimony/ber nanke20070328a. htm (accessed June 10, 2013).

10. See, for example, Craig Torres and Alison Fitzgerald: "Greenspan Says Housing Market 'Speculation' Is Unsustainable," bloomberg.com, May 20, 2005, avail able at http://wwwbloomberg.com/apps/news?pid=newsarchive.ssidmazbst whe5fow (accessed June 10, 2013).

11. See Jean-Paul Gitoussi: 2013, Le théoreme du lampadate, Paris: Les liens qui Liberent.

12. Ben Bernanke: "On the implications of the financial crisis for economics," Conference co-sponsored by the Center for Rcononic Pollcy Studies and the Bendheim Center for Finance, Brinceton University, Princeton, NI: US Federal Reserve, September 24,2010 , avallable at http:/www federalreserve gov/newsevents/speech/benarke20100924a.hm (accessed June 10, 2013).

13. Ibid.

14. This is a very conservative number based on a comparison of GDP in each year since the crisis and a straighttorward extrapolation of where the economy would be had there not been a crisis. The dispanity for the US in 2014 is in excess of $15 \%$ and for burope is even larger.

15. See his April 2006 lecture at Trinty University in San Antonio, Texas, avatlable at http:/www.trinity.edu/nobel/Prescott/Prescott Webquotes.htm (accessed June 12,2013 )

16. This discussion can be thought of as takeng off where pitoussi left off in his wonderful description of the evolution of macoeconomic theory, in his introduction to Modern Macroeconomic Theory, Basil Blackwell 1983.

17. B. Greenwald and J. E. Stiglitz: "Keynesian, New Keynesian, and New Classical Lconomics, "Oxford Economic Papers, 39: pp. 119-1.33, March 1987.

18. See I. F. Stiglitz: "Kn formation and Capital Matkets" in Williarn E. Sharpe and Cathryn Cootner (eds), Financial Economics. Essays in fonor of Panl Cootner Prentice Hall, New Jersey, 1982, pp. 118-158; and the introduction to its reprinting in Selected Works of Yoseph E. Stighitz, Volune II, Oxford: Oxtord University Press, 2013, pp. 55-84.

19. Of coutse, with homogentous labor/perfect information/no search costs, the efficiency waye theories are no longer relevant. In the representative agent models, the only reason that labor is not fully employed is some form of wage rigidity. But this is an artificial consequence of these artificial assumptions.

20. Willam Easterly, koumeen Islam, and J. E. Stighitz: "Shaken and Stirred Explaining Growth Volatility," Ammual Bank Conference on Development Economics 2000, Washington: World Bank, 2001, pp. 191-212; and "Shaken and Stitred; Volatility and Macroeconomic paradigms for Rich and Poot Countries," in Advances in Macroeconomic Theory, Jacques Dreze (ed,) IEA Conference Volume, 133, Houndsmill: Palgrave Macmillan, 2001, pp. $353 \mathrm{~m} 372$. 
21. Brace Greenwald ant 1. E. Stiglitz: "Externalities th fconomies with Imperfect Information and Incormplete Markets," Quarterly foumal of Economics, $101(2)$ : pp. $229 \sim 264$, May 1986.

22. Thete is a growing literature focusing on exploring the macroeconomic implications of the externalities that Greenwald and I identified, e.g. not just for self-selection and incentive compatibility constraints, but also for bontowing constraints. See, for example, Jeanne, Olivier and Anton Korinek: "Excessive Volatility in Capital flows: A pigouvian Taxation Approach" American bonomic Review, 100(2): pp, 403-407, 2010; and "Managing Credit Booms and Busts: A Pigotwian Taxation Approach," NBER Working Paper Number 16377,2012 , available at http:/www.nber.org/papers/w16377.pdf (accessed June 10,2013).

23. See, for example, J. E Stiglit. "Alternative Theoties of Wage Determination and Unemployment in L.D.C.'s: The Labor Turnover Model," Quarterly Joumal of Economics, 88(2): pp. 194-227, May 1974; and Carl Shapiro and 1. c. Stightz: "Equilibrium Utremployment as a Worker Discipline Device," Ameticun Iconomic Review, 74(3): pp, 433-444, June 1984 .

24. They also provided, I believe, a better explanation of nominal nigidities than the fasthonable ment cost theory, See B. Greenwald and I. E. Stiglitz: "Toward a Theory of Rigidities," American Econontic Review, 79(2): pp. 364-369, May 1989 .

25. 1. W.sher: "The Debt Deflation Theory of Great Depressions," Econometrica, 1.(4): pp. $337-357,1933$.

26. Even if wages and prices fall, it toes not mean that real wages change. That depends on differences in the rates of changes in wages and prices. There can be real wage rigidities even in the presence of flexibility of nommal wages and prices. See R. Solow and J. E. Stiglitz: "Output, Employment and Wages in the Short Rum," Quarterly Jounal of Economics, $82:$ pp. 537,560 , November 1968.

27. See Charles Kindleberger: Mantas, Panics, and Crashes: A History of Financial Crises, New York: Basic Books, 1978.

28. Greenwald and Stiglitz show how price flexibility can lead to large balance sheet effects, leading tirms curtail production, employment, and investment, amplifying the effect of any shock. (This is sometimes refered to as the financial accelerator.) (Because it takes time for balance sheets to be restored, the effects of the shock are likely to be persistent.) The effects can be further amplified as a result of impacts on bank balance sheers, leading them to contract lending. See B. Greenwald and 1. L. Stigliz: "Financial Market Imperfections and Business Cycles," Quarterly foumal of Economics, 108(1): pp. 77 114, February 1993; and B. Greenwald and ]. L. Stiglity: Towar as a New Paradigm in Montary Econonics, Cambridge: Cambilige University Press, 2003.

29. Or if thete were multiple steady states, stch that with a small change in state variables, the economy entered into a ciffer orbit of attraction.

30. I do not, however, beleve that one can explain the crisis of 2008 - the sudden change in the aggregate output and employment, with little change in the state variables - by such models. It was not that the economy suddenly shifted from one equilibrim to another. What happened is better described by a model of disequilibitum: the econony was expetiencing a bubble, but of course didn't realize it. Bubbles always break, and it was the unwinding of the bubble - and the gratlual realization that there had been a bubble - that was at the root of the marked change in macroeconomic aggregates.

31. J. Siglitz and Mattin M. Guzman: "Pseudo-weath and Consumption Fluctuations," Columbia University Working Paper, presented at the Work Congress of the IFA, June, 2014 .

32. J. Scheinkman and W. Xiong: "Overconfitence, Short-sale Constraints and Bubbles," Princeton Economic Theory Working Papters $9873496611 \mathrm{cla} 57373801367 \mathrm{f}, 2003$.

33. See Jean-Pau Fitouss: "Wage Distribution and Unemployment," American Economic Reviuw, papers and Procedings, 84(2): pp. 59-64, May 1994; and Jean-Paul Fitoussi and Francesco Saraceno: "Inequality, the Crisis and After," Rivista di politica Economica, Série ll, fascicule l-lll pp. 9 m, January. March 2011.

34. See, for example, K. E. Dynan, J. Skinner, and S. P. Zeldes: "Do the Rich Save More?" Joumal of Pohitical Economy, 112(2): pp. 397-444, 2004.

35. See k. Dyman: "Is a Kousehold Debt Overhang Holding Back Consumption?" Brookings papers on Economic Activity, pp. 299-362, spring 2012, avaliable at http:/ www brookings.edu/ /media/Projects/BPEA/Spring\%202012/2012a Dynan.polf (accessed Jutte 10,2013); and A. Mian, K. Rao, and A. Sufi: "Tousehold Balance Sheets, Consumption, and the Economic Slump," June 2013 working paper, avalable at http:/papers.ssm,com/sol3/papers. cfrm?abstract idm 1961211 (accessed une 12, 2013).

36. See discussion in Dynan, Skinner, and Zeldes, op. cit; Stephen p, Zeldes fiscusses such constraints in more detal in "Consumption and Liquidity Constraints: An Empirical Investigation," Joumal of Political Economy, 97(2); pp. 305-346. 1989

37. Robert lucas: "The Industrial Revolution: past and present", 2003 Annual Report Essay, The Federal Reserve Bank of Minneapolis, May 1. Accessed from http//wwwminneapolisfed.org/publications_papers/pub_display. cfm?icm 3333 (accessed lune 18, 2014).

38. For an excellent discussion of these issues, see Dean Baker: "The Myth of Expansionary Fiscal Austerity," CEPR, Washington, DC; $\mathrm{MMF}$ 2010, kconomic Outlook, chapter 3; and Arjun Jayadev and M. Konczal: "The Boom not the Slump: "The Right "Tine for Austenty," The Roosevelt Institute, August 23, 2010.

39. Alberto Alesma and Sivia Ardagna: "Large Changes in wiscal Policy: "Taxes versus Spending," in Tax Pollcy and the Economy, Jeffrey R. Brown (ed.), vol. 24, Chicago: University of Chicago Press, pp. 35-68, 2010 .

40. See, for example, International Monetary fund: "Will ll Hurt? Macroeconom Effects of Fiscal Consolidation, "in World Economic Outlook; Recovery, Risk, and Rebalancing; Washington, D.C.: MMF, pp. 93-124, 2010 .

41. Though not designed to be beggar-thy-neighaor policies, they have effects that are much akin to such policies. See also J. P. Fitoussi: Le theoreme än ampalaire, op. cit

42. For a discussion of some of the issues raised here, see Robert M. Solow: "Fiscal Policy," in Olivier Blanchard, David Romer, Michael Spence, and Joseph Stiglitz (eds), In The Wake of the Crisis: Leading Ecowomists Reassess Economic Policy, Cambridge, MA, The MIT Piess, 2012, pp. 73-76.

43. See Stiglitz, Sern, and Jitoussi, op, cit. 
44. Recent econometric studies do show significant multipliers, for example around 1.5. See Emi Nakamura and Ion Steinsson: "Fiscal Stimulus in Monetary Union: Evidence from US Reglons," American Economic Review, American Lconomic Association, 104(3): pp. 753 792, March, 2014.

45. Alexander, leeld: A Great Leap Fonward: 1930 sepression and U.S, Economic Growth, New Haven: Yale University Press, 2011.

46. The St. Louis ked tracks personal savings tate on its website at http://research. stlotisfed.org/fred2/data/PSAVERT.txt (accessed October 31, 2012); the historically low personal savings rates duing the bush years are clear here.

47. Government expenditures do not even have to be investments; if government consumption expenditures and private consumption expenditures are complements, then there will be cowding in of consumption. Moreover thete is another channel through which crowding in of investment, to which we alteady alluded, takes place when government investment and private investrnent are complements.

48. P. Neary and J. E. Stigltz: "Toward a Reconstruction of Keynesian Economics: Expectations and Constrained Equilibria, "Quarterly Journal of Econontics, 98, Supplement: pp. 199-228, 1983.

49. J. E, Stiglitz, keefall, op. cit. and Linda Bilmes and J. E. Stiglitz: The Three Trillion Dollar War: The True Costs of the Iraq Conflict, WW Norton, 2008.

50. Reinhart and Rogoff suggested, furthermore, that increased indebtedness beyond a $90 \%$ dettoto-GDP ratio wond lead to significantly lower growth. (Reinhatt, M. Carmen, and kenneth S. Rogoff: "Growth in a Time of Debt," American Econonic Review 100(2); pp. 573 578.) Putting aside the fact that their analyses ignored the central point we have emphasized - the forms of expenditure and the circumstances of the economy make a big difference - their work has since been extensively criticized. See, for exarnple Thomas Herndon, Michael Ash, and Robert Pollin: "Does Wligh Public Debt Consistently Stifle bconomic Growth? A Critique of Reinhart and Rogoff," Cambridge Joumal of Ecomomics $38(2)$; pp. 257-279, 2014

51. Anton Korinek and J. C. Stiglitz: "Dividend Taxation and Intertempotal Tax Arbitrage," Tournal of Public Economics, $93(2009)$ : pp. $142-159$.

52. See footnote 57 .

53. Martin Wolf: "Austetity loses an article of fatth", Financial Times, April 23 , 2013, Accessed at http:/www,ftcon/cms/s/0/60b7a4ec-ab58-11e2-8c6300144 feabdco.htmiffaxzz353a9n6Mv, on June 18,2014 .

54. Moreover, the standard competitive models do not provide an explanation for why a high level of indebtedness should lead to a high level of persistent unemployment. Even if it led to a lower level of aggregate consumption at a given set of wages and prices (including interest rates), thete is some set of wages and prices at which full employment could be attaned. Our analysis above pointed out, however, that the matural adistments mechanisms may actually lead to increased unemoloyment.

55. Of course, in an open economy model, if individuals in a country become indebted to those abroad, it lowers their wealth, and thus their standard of living. This just affects who gets the benefits of the country's output, not the level of outpart on its rate of growth.

56. What should matter (in the standard theory), of course, for investment is the real product interest rate, not the real consumption interest rate, and when there are large changes in relative prices, as occurred during the Great Depression, these can tiffer markedy.

57. Some (Woolford, 2003,2009 ) have suggested that what is required is a credible commitment to inflation (e.g., through price- level targeting, which implies when there is less than nomal inflation now, perhaps due to deflam tionary pressures atising from excess capacity, there will be higher than nomal inflation in the future). But even if the expected real interest rate were the critical deterninant of investment (which we suggest it is not), there is no way that the monetary authority could commit itself to such a policy. See M. Woodford, "Optimal interest-rate smoothing", The Review of Economic Studies, $2003,70(4): 861-886$. and M. Woodford, Convergence in Macroeconomics: Elements of the New Synthesis. American Fonomic lournat: Mactoeconomics, $2009,1(1): 267.279$.

58. With the increased spread going to the financial sector, with little positive effect on aggregate demand.

59. I helieve that it is reasonable for the fed to ignore this efect; but this simply illustates the inconsistencies in the use by the fed and other central banks of some of the standard models based on full rationality. In practice, they seem to use the model when it produces result they like, and not otherwise. Thus, for instance, a preannounced policy of a temporary interest tate cut should have little effect on asset prices or demand, since long-run prices and hifetime budgets should be telatively unaffected. See the discussion below.

60. For a formal model of this process, see J. E. Stiglitz: "Monetary Policy in a Multipolar World," forthcoming in the proceedings of the Intemational Lconomics Association's 2012 Ezmir roundtable.

61. See, for instance, his 2006 "Macroeconomics and institutions," Angelo Costa Lecture, Rivista di Political ticonomica, $95(6)$ : pp. $9-30$

62. See, in particulat, Jean-Paul Fitoussi: "Following the Collapse of Communism, Is There Still a Middle Way?" in Coln Crouch and Wolfang Streeck (eds), Political Economy of Modem Cafitalism, London: Sage Publications, October 1997, pp. 148 160 . 